\title{
Design and Construction Risk Management of Souq Waqif Station of Gold Line, Doha Metro
}

\author{
Spyridon Konstantis \\ skonstantis@qr.com.qa \\ Qatar Rail, Doha, Qatar \\ Spyros Massinas \\ smassinas@goldlinemetro.qa \\ ALYSJ JV, Doha, Qatar
}

\begin{abstract}
The case of redesigning Souq Waqif station by raising the base slab formation level due to significant water inflow during the excavation and dewatering works and the break in activities of two EPB TBMs under adverse hydrogeological conditions is presented. The station is at close proximity with a structure of great heritage value and the monitoring records prior to TBM break in, indicated unacceptable ground deformation values. Back analyses were performed and contingency measures defined and implemented on site. The station redesign had also to take into consideration an adjacent future development affecting the station, the design basement levels of which increased during the station excavation.
\end{abstract}

Keywords: Station; Water ingress; Ground deformations; Stability; Redesign

\section{INTRODUCTION}

The Doha Metro Gold Line is part of the Qatar Integrated Railway Project (QIRP) and as shown in Figure 1 it extends from Ras Bu Abboud Station in the east (near Hamad International Airport), crosses Msheireb Major Station and reaches Al Aziziyah in the west (near Aspire Zone). The line comprises approximately $15 \mathrm{~km}$ of twin bore TBM tunnels, 24 cross passages and a number of underground structures, including 11 stations (Msheireb station was built by others), an underground stabling yard with light maintenance and washing facilities, switchboxes and an emergency exit. The project was awarded to ALYSJ Joint Venture, formed by Aktor of Greece, Larsen \& Toubro of India, Yapi Merkezi \& STFA of Turkey and Al Jaber Engineering of Qatar.

Souq Waqif station is located on the tunnel section between the Musheireb main interchange and the National Museum of Qatar stations. It is a $226 \mathrm{~m}$ long and approximately $26 \mathrm{~m}$ deep station constructed as a single integral reinforced concrete structure with the cut and cover method. In close proximity and inside the construction influence zone of the station and the twin bore tunnels, a Mosque complex structure of great heritage value for the State of Qatar is located (see Figure 2).

During the temporary works and dewatering activities for the station excavation with approximately $2 \mathrm{~m}$ left until the formation level and prior to the arrival of the two EPB TBMs, significant water inflow occurred mainly from the bottom of the excavation. Given the schedule criticality and constraints for casting the station slab to enable passing through of the TBMs, it was decided to modify the original station design and raise the 
base slab formation level. From a tunnel alignment point of view, this was feasible as the TBMs were in a sufficient distance from the station and the alignment could be accordingly adjusted. The station redesign had also to take into consideration the future PEO (Private Engineering Office) development on the north side of the station, which was foreseen to have 4 basements and was planned to be constructed while the station would be operational.

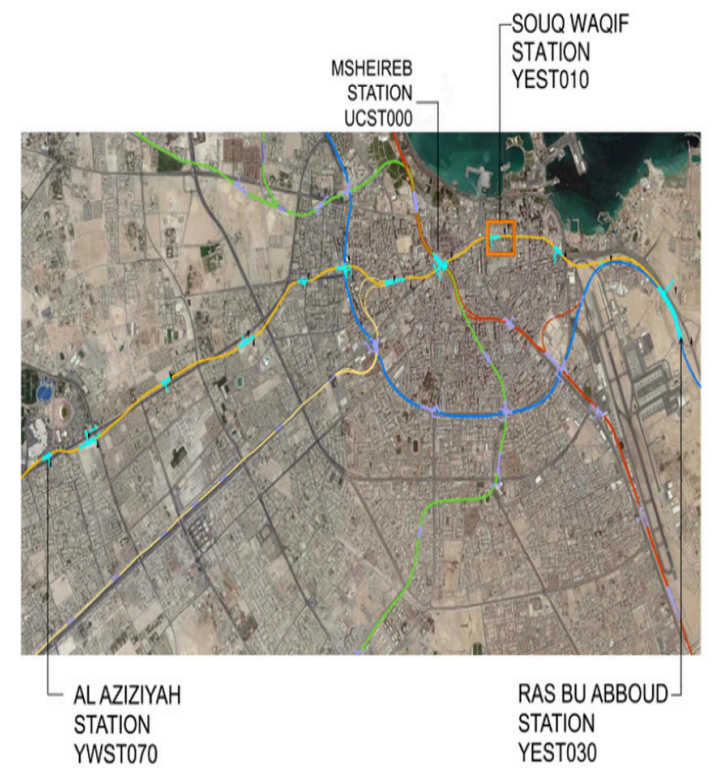

Figure 1: Doha Metro (Gold Line alignment is shown with yellow color)

In addition to the water inflow, ground deformations on the east headwall, near the Mosque occurred which exceeded the predefined trigger levels (Construction impact Stage 3, 2019). In order to ensure the integrity of the Mosque from the induced ground deformations and the safe reception of the two TBMs through the east headwall, a back analysis was performed and contingency measures were defined and implemented on site, as per the response action plan (Konstantis \& Massinas, 2017).

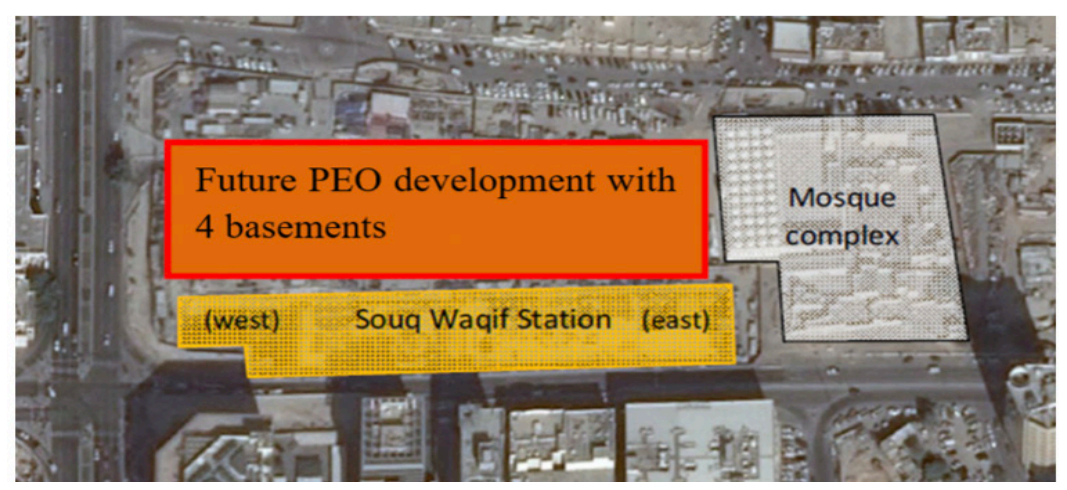

Figure 2: Souq Waqif station plan view 


\section{GEOTECHNICAL AND HYDRO-GEOLOGICAL CONDITIONS}

The geological units of the concerned area can be grouped into four main categories from newest to oldest geologically: superficial material (made ground, quaternary deposits and/or residual soil deposits); Simsima Limestone with varying degrees of weathering; Midra Shale and Rus Formation (Geotechnical Interpretive Report, 2019). Due to the presence of limestone type geological units, an assessment on the presence of cavities and voids was made prior to the station excavation based on the information provided by the additional geotechnical investigations, in addition to the geophysical campaign. Small karst features had been identified within the footprint of the station but such features were interpreted to be small and were assessed as unlike to affect the temporary works and construction activities. In Figure 3, the as built hydrological conditions are presented, where the active dewatering was capable to develop a drawdown groundwater depression cone.

On the 25th August 2015, during the excavation works and with approximately $2 \mathrm{~m}$ remaining ground to be excavated until the base slab formation level was reached, a karstic feature was encountered resulting in excessive water inflows inside the station (Figure 4). This adverse condition posed great difficulties to the continuation of the station excavation and hindered the base slab casting to enable the timely passing through of the approaching TBMs, a critical schedule activity associated with contractual milestones. Prior to encountering the karst feature, the water inflow recorded due to the active dewatering was around $12,000 \mathrm{~m} 3 /$ day, whereas post the occurrence of the event, the water inflow recorded was $24,600 \mathrm{~m} 3 /$ day as an average value with a recorded maximum of $56,688 \mathrm{~m} 3 /$ day.

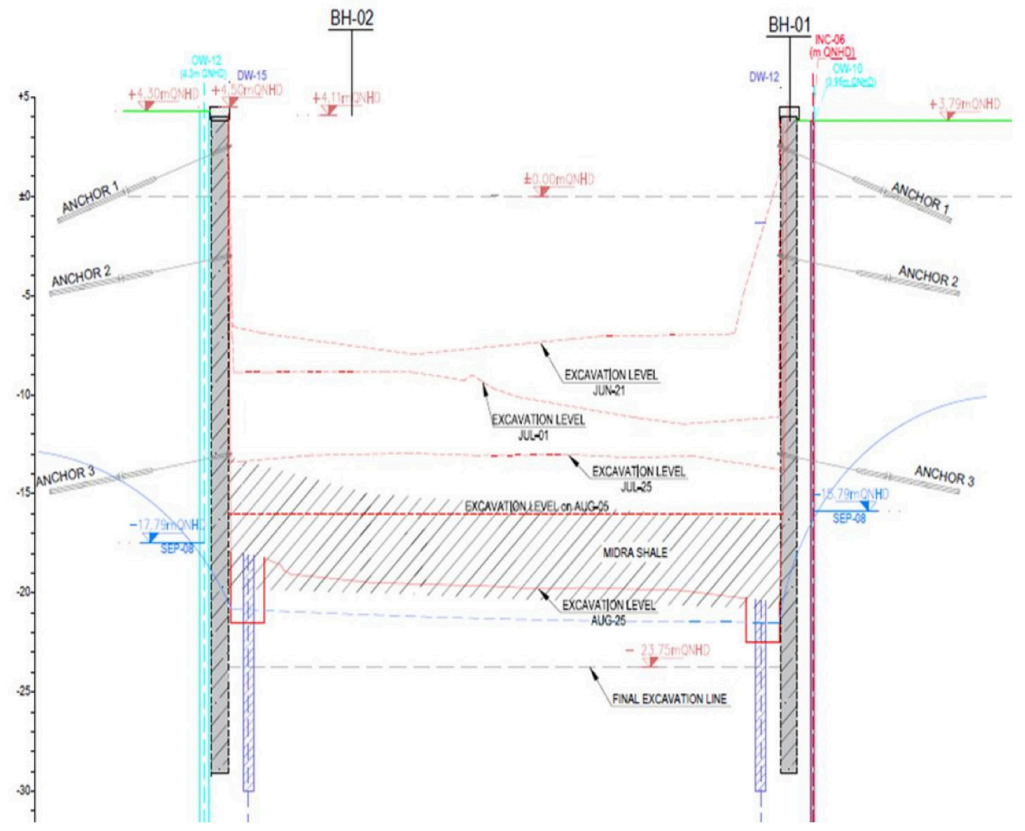

Figure 3: Prevailing hydrogeological conditions and active dewatering with dewatering wells 


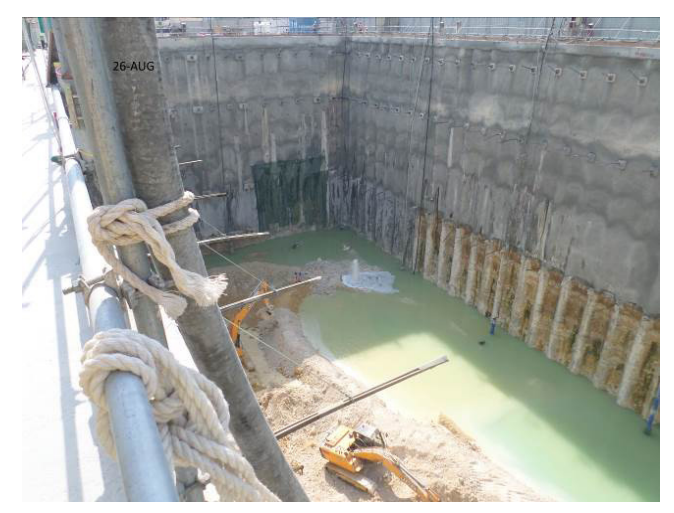

Figure 4: Water ingress inside the station due to karstic feature

In order to identify the location, extent and condition of the karstic feature, additional geotechnical investigations were carried out, including a thorough MASW geophysical campaign (see Figure 5, left). Following a comprehensive and thorough analysis and interpretation of all the available information, the possible configuration and extent of the karstic feature was determined (see Figure 5, right), which was gradually and carefully filled and sealed with grout. In addition, before the re-commencement of the works and in order to further investigate the possibility of more and possibly interconnected karsts, additional geophysical surveys were executed. As per the results, no further karst features or channels were found.
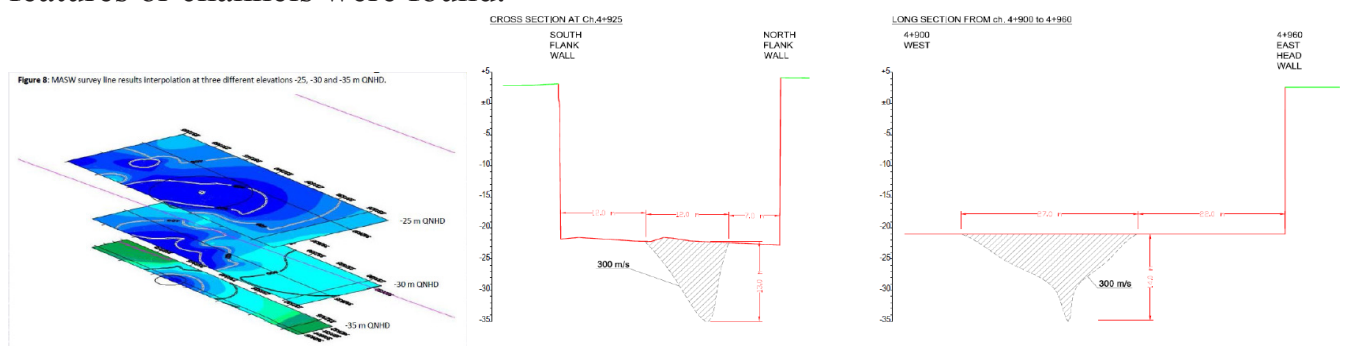

Figure 5: MASW survey line results interpolation at different elevations (left) and configuration and extent of the encountered karstic feature (right)

\section{ORIGINAL STATION DESIGN}

The original station design foresaw a $3.4 \mathrm{~m}$ layer of unreinforced concrete over the station base slab to counterbalance the buoyancy effect (see Figure 6). Due to the planned future development next to the station box and the requirement for direct connection of the station's concourse level with the development, there was very limited overburden available for landscape purposes and utilities, which was practically neglected in the flotation checks. In addition and as per the Qatar Rail Employer's Requirements, the groundwater design level was considered to be on the ground surface. That was considered the worst case given the proximity of the station to the sea and the adjacent construction and dewatering works, which were taking place concurrently in the area. In fact and based on past aerial photographs, it was identified that the station was located very close to the original coastline. 


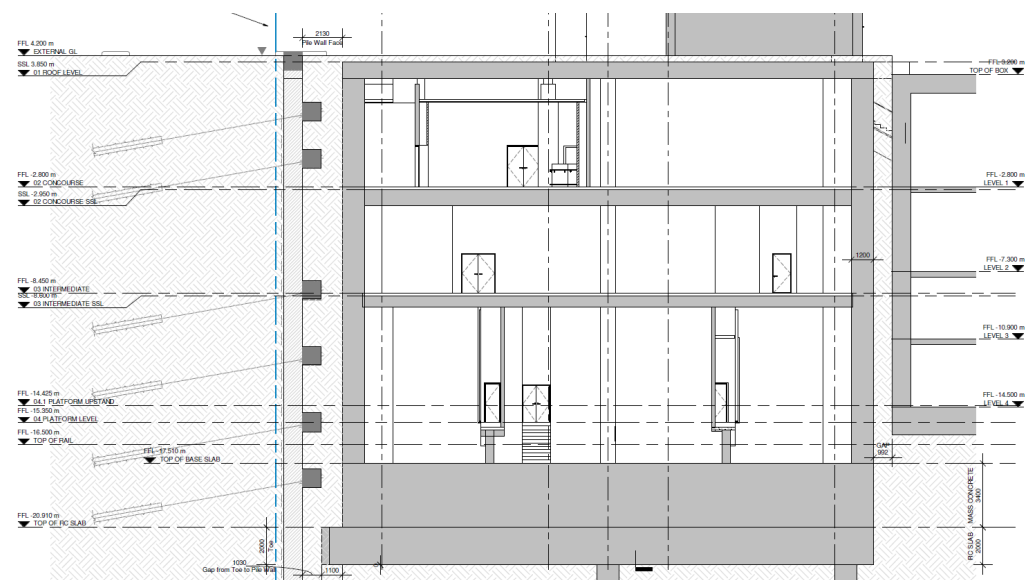

Figure 6: Station cross section of the original design

The station's ELS (Excavation and Lateral Support) was based on the Geotechnical Interpretative Report (GIR) findings and comprised contiguous and soldier anchored pile wall. With regards to groundwater inflow and management, the design assumption was made that the water table draw-down would be achieved with manageable water inflow quantities. Thus no water-tight system was foreseen to be required. Any possible water pressure at the Midra Shale layer would be relieved by systematic installation of drainage holes. As a groundwater control risk mitigation measure, the design specified grouting to be executed in the perimeter of the excavation for void filling. As per the original design, the formation level was foreseen in -22.9m QNHD (Qatar National Height Data). When the karstic featured was encountered, the excavation level in that area had reached approximately $-20.5 \mathrm{~m}$ QNHD.

\section{MODIFIED STATION DESIGN}

As already mentioned above, the schedule criticality of the passing through of the approaching TBMs necessitated the urgent casting of the station's base slab without delay. Given the prevailing conditions, the risk of reactivating the sealed karstic feature or encountering new ones during the remaining excavation works and thus causing again excessive water inflow in the excavation pit was assessed as high and classified as unacceptable. Therefore the decision was taken to halt the excavation works at the level reached and modify the structural design of the station by raising the base slab to the already excavated level. In order to counterbalance the buoyancy and satisfy the minimum acceptable factors of safety against flotation with the reduced base slab mass, several options were considered and evaluated (see Figure 7).

The option of constructing tension piles was rejected due to the increased construction costs, schedule constraints as well as the durability requirements and the high risk of reactivating the sealed karst or encountering other karsts. Other options considered were the connection of the station concrete structure with the excavation support pile wall with dowels or the construction of a base slab shear key. However both options were also discarded mainly due to the additional construction costs, the questionable durability of the pile temporary wall and the schedule constraints in constructing the shear key. 
The option finally adopted was to mobilize the interface resistance between the station and the ground (see Figure 8) and increase the dead weight of the concrete structure by increasing the wall thicknesses, where possible. This option eliminated the schedule risks as any additional works required (e.g. increase of thickness of the concrete walls) could be constructed following the reception, transfer and relaunch of the TBMs.

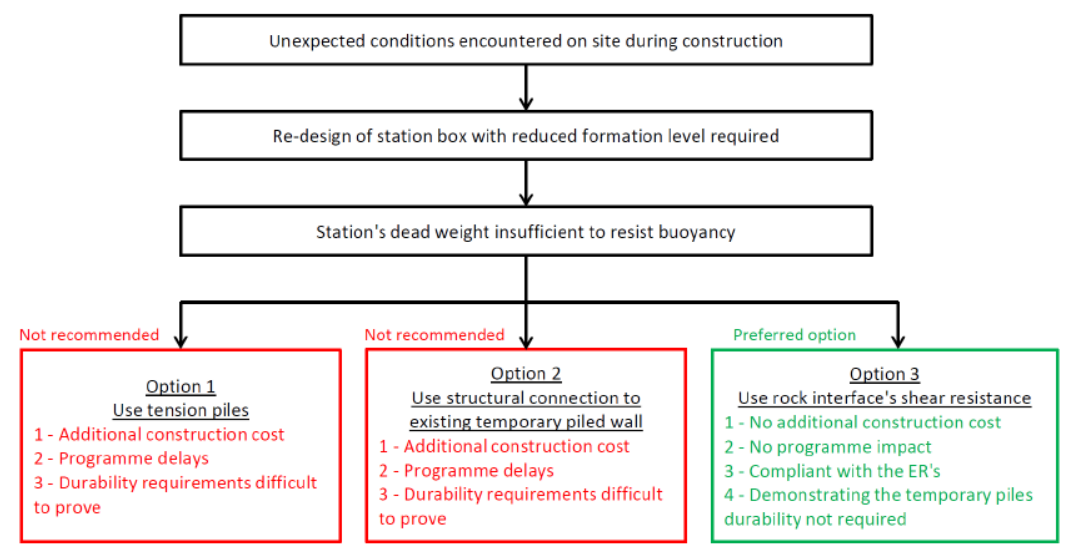

Figure 7: Comparative assessment of alternatives considered to counterbalance buoyancy

At the same time and as the design of the adjacent future development was in parallel progress, it was identified through the stakeholder interface and coordination management that the future structure's design foresaw the excavation formation level at approximately $-19 \mathrm{~m}$ QHND. That meant that when the future development would be excavated next to the operational station, the station box would then be subject to asymmetric lateral loading, with soil and water pressure acting only on one side. The analysis determined that this asymmetric loading and in particular the water pressure would lead to overturning and sliding of the station box with detrimental effects since the potential movement of the concrete box would result in damages to the operational station/tunnel segmental lining interface in a water bearing regime.

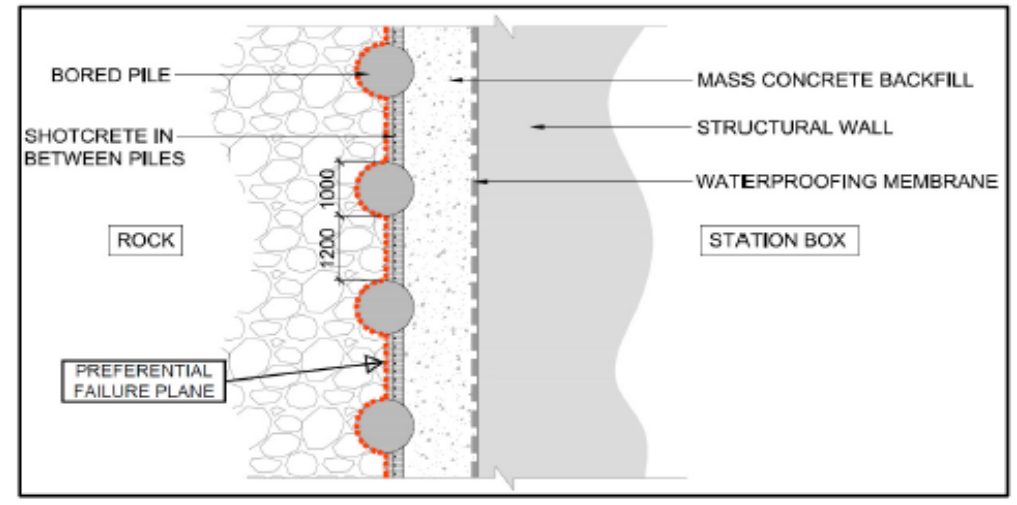

Figure 8: Plan cross section of the station box permanent and temporary works interface

As per the Qatar Rail Employer Requirements and the applicable Qatari Law, any third party structures located inside the Final Rail Route Approval and in particular 
the defined Protection Zone must receive a No Objection Certificate (NOC) for any construction works. In this process, certain restrictions and conditions can be set by Qatar Rail in the design and construction execution and method statements of these structures in order to ensure than no adverse impact on the Rail assets will occur.

In order thus to ensure that no asymmetric water pressures would be exerted on the station, the condition was set that continuous dewatering will have to take place during the future construction until the future structure is constructed and the backfill in between the station and the development is in place (see Figure 9).

For the dewatering activities during the excavation of the station box, dewatering wells were installed in the perimeter of the station between the temporary support pile wall and the extrados of the station external walls. The dewatering wells on the south wall were retained with the objective to be handed over to the contractor of the future development to carry out the necessary dewatering works as outlined above.

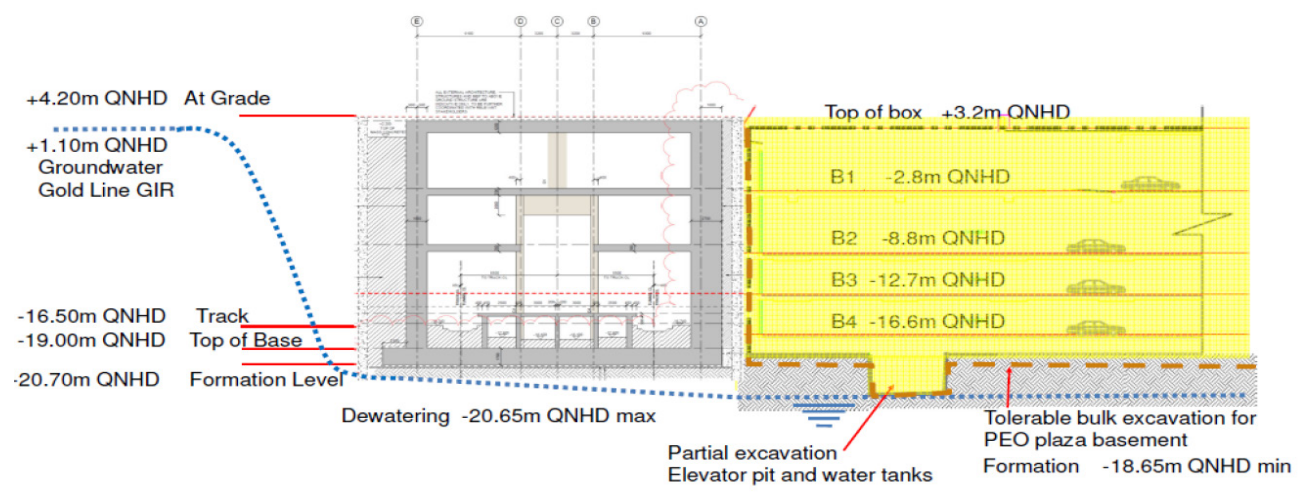

Figure 4: Cross Section of Future Development Excavation and Groundwater Control

Figure 9: Cross Section of future development excavation and groundwater control

Given the criticality of the future dewatering works with respect to the station's structural integrity and robustness, a thorough risk assessment was carried out with the objective to put appropriate measures in place and reduce the risk to As Low As Reasonably Practicable (ALARP). One of the major technical and construction risk identified was the blocking of the retained dewatering wells. Thus, an effort was made, albeit the tight spatial constraints, to configure this area in such a way that new dewatering wells could be installed. In some cases, positions for new dewatering wells were preselected and the installation of the casing in the top meters was carried out to enable insertion of the drilling rig without the need for utility diversions or removal of any other obstacles (see Figure 10). 

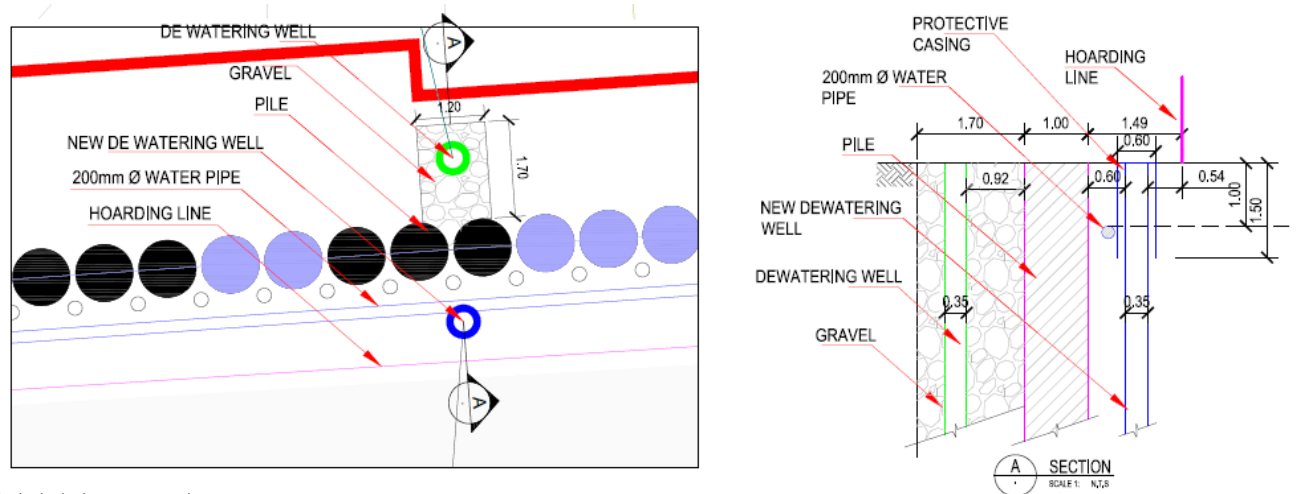

Figure 10: Dewatering wells encasement detail

In addition and in order to ensure that the groundwater flow path shown in Figure 9 will be retained during the future dewatering activities and no water pressure will be exerted on the station base slab, transverse drain channels were introduced and constructed below the slab.

As per the original design, the area between the temporary support pile wall and the external wall of the station would be backfilled with permeable rock type fill material. With this configuration in place, the groundwater would be filtered and led to the pumps inside the dewatering wells and any overpressure would be relieved through the drainage channels below the base slab. However, given the spatial constraints which dictated the backfilling and compaction equipment to be used, the productivity rate was lower than anticipated. Hence in order to improve the backfill construction performance which would also enable the earlier decommissioning of the dewatering system, it was decided by the contractor to replace the rock type fill with lean concrete. The backfill with impermeable material necessitated thus the construction of an encasement around the dewatering well, which was filled with permeable material (see Figure 10 and Figure 11).

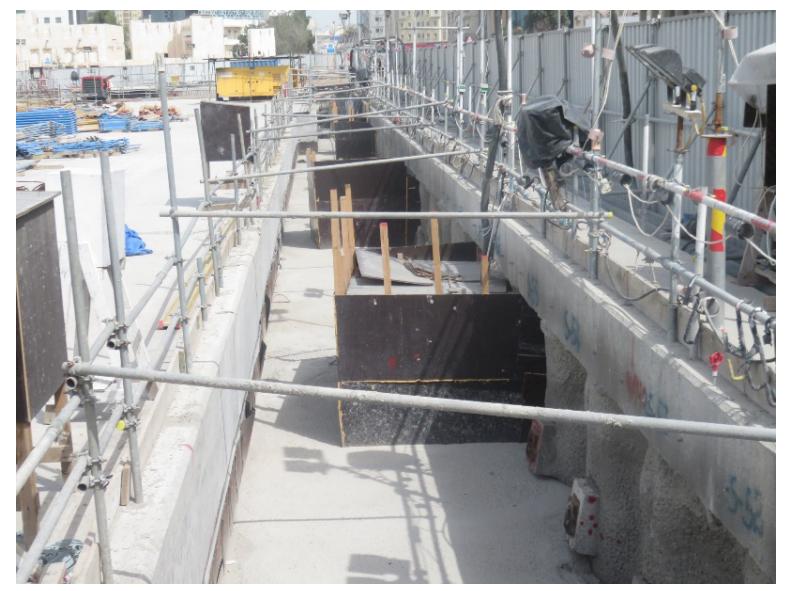

Figure 11: Encased dewatering well inside the lean concrete backfill 


\section{CONCLUSION}

Despite the tight and challenging schedule constraints and the significant water inflow which occurred during the excavation works, which necessitated the design modification of the station during its construction, as well as the concurrent ground deformations on the east headwall which exceeded the predefined trigger levels, the base slab was cast on time, the TBMs arrived without any issues and they continued their journey towards their successful final breakthrough which occurred prior to the contractual milestone.

\section{ACKNOWLEDGEMENTS}

The authors would like to thank Qatar Rail and ALYSJ JV for their permission to publish this article.

\section{REFERENCES}

Construction impact Stage 3 (2019). Risk assessment for Complex Mosque at Souq Waqif Station, Qatar Rail.

Geotechnical Interpretive Report (2019). Souq Waqif Station, Qatar Rail.

Konstantis, S. \& Massinas, S. (2017). Qatar Rail, Doha Metro - Gold Line Project / Assessment of TBM breaking-in activity into Souq Waqif station under adverse conditions. ITA World Tunnel Congress 2017. 